\title{
INFLUENCE OF A CRYOGENIC TREATMENT ON THE FRACTURE TOUGHNESS OF AN AISI 420 MARTENSITIC STAINLESS STEEL
}

\author{
VPLIV PODHLAJEVANJA NA LOMNO ŽILAVOST \\ MARTENZITNEGA NERJAVEČEGA JEKLA AISI 420
}

\author{
Germán Prieto ${ }^{1,2}$, W. R. Tuckart ${ }^{1,2}$, Juan Elias Perez Ipiña ${ }^{2,3}$ \\ ${ }^{1}$ National University del Sur, Tribology Group, Engineering Department, Bahía Blanca, Argentina \\ ${ }^{2}$ National Scientific and Technical Research Council (CONICET), Buenos Aires, Argentina \\ ${ }^{3}$ Comahue National University, Engineering Faculty, Fracture Mechanics Group, Neuquén, Argentina \\ german.prieto@uns.edu.ar
}

Prejem rokopisa - received: 2016-06-23; sprejem za objavo - accepted for publication: 2016-11-16

doi:10.17222/mit.2016.126

\begin{abstract}
Cryogenic treatments have been employed over the past three decades for both tool and high-alloy steels to improve their wear resistance, mainly through the transformation of retained austenite and the precipitation of fine carbides. However, as the enhancement of one material property is often at the expense of another, it is interesting to evaluate the effect of this type of treatments on the fracture toughness. The objective of the present work was to determine the plane-strain fracture toughness of a cryogenically treated low-carbon AISI 420 martensitic stainless steel by means of standardized fracture tests, performed in accordance with the ASTM E399 and ASTM E1820 standards. In this study, it was experimentally demonstrated that cryogenically treated specimens showed a simultaneous increase in the $K_{\mathrm{IC}}$ and hardness of $30 \%$ and $5 \%$, respectively, compared to conventionally treated specimens.
\end{abstract}

Keywords: cryogenic treatment, carbide refinement, plane-strain fracture toughness, low-carbon martensitic stainless steel

Obdelava s podhlajevanjem v zadnjih treh desetletjih, tako za orodja kot za visokolegirana jekla, pomeni izboljšanje njihove odpornosti proti obrabi, predvsem zaradi preoblikovanja zadržanega avstenita in zgoščevanja finih delcev. Kakorkoli že, izboljšanje enega materiala je pogosto, vendar na račun drugega, zato je zanimivo oceniti učinek takega tipa obdelave na lomno žilavost. Predmet pričujočega dela je bila določitev lomne žilavosti kriogensko obdelanega nizkoogljikovega martenzitnega nerjavečega jekla AISI 420, s pomočjo standardiziranih testov zlomov, izvedenih v skladu s standardoma ASTM E399 in ASTM E1820. V študiji je bilo s poizkusi dokazano, da so kriogensko obdelani vzorci pokazali hkratno povečanje $K_{\mathrm{CI}}$ in trdote za $30 \%$ in $5 \%$, v primerjavi s konvencionalno obdelanimi vzorci.

Ključne besede: obdelava s podhlajevanjem, prečiščenje delcev, lomna žilavost, nizkoogljočno martenzitno nerjaveče jeklo

\section{INTRODUCTION}

AISI 420 is a martensitic stainless steel, with carbon contents ranging between $0.15 \%$ mass fraction and $0.40 \%$ mass fraction, while its corrosion resistance comes from the addition of chromium (12-14\% mass fractions). Due to its balance between mechanical properties and the corrosion resistance, it is widely used in power generation, turbine blades, compressors, oil extraction, chemical, petrochemical and surgical equipment. Thus, the enhancement of its mechanical properties, in particular its wear resistance, is of technological interest. ${ }^{1-4}$ In this sense, deep cryogenic treatments (DCT) are increasingly utilized for steels and other groups of alloys for improving their tribological performance. This kind of treatment possesses several advantages, such as its relative low cost, ease of application, low environmental impact and, especially, its volumetric effect. This means that the whole volume of a workpiece exhibits a wearresistance enhancement in comparison to superficial techniques, such as plasma nitriding, electrodeposited coatings or case carburization.

Traditionally, the improvement of the tribological resistance of steel alloys was attributed to the transfor- mation of retained austenite ${ }^{1,5-7}$ and to the refinement of secondary carbides. ${ }^{8-10}$ Recent studies have shown that the martensitic transformation of retained austenite at low temperatures involves a plastic deformation of virgin martensite. ${ }^{4,11}$ This plastic deformation causes the capture of immobile carbon atoms by gliding dislocations, forming carbon clusters that can serve as sites for nucleation of finer carbide particles during tempering, therefore influencing the carbide distribution. ${ }^{12} \mathrm{M}$. Villa et al. ${ }^{13}$ analyzed the generation of compressive strains in austenite after the transformation of martensite at a low temperature. These strains influence the stability of austenite during the subsequent tempering. However, when this transformation occurs below $-133{ }^{\circ} \mathrm{C}$, no compressive strains build up in austenite. It should be noted that this mechanism requires the presence of significant amounts of retained austenite after the quenching and before the cryogenic cooling, which is not expected to be the case for AISI 420 due to its chemical composition and excellent hardenability. ${ }^{14,15}$

In our prior work ${ }^{16}$, we tested several processing routes, and the one which yielded the best combination of properties was selected to continue studying the effect 


\section{G. PRIETO et al.: INFLUENCE OF A CRYOGENIC TREATMENT ON THE FRACTURE TOUGHNESS ...}

of cryogenic treatments on tribological properties and fracture toughness in the context of a $\mathrm{PhD}$ thesis. ${ }^{17}$ Regarding the wear behavior, we reported, in a preliminary article ${ }^{10}$, that cryogenic treatments increase the wear resistance of AISI 420 by $35-90 \%$ in comparison to conventionally treated specimens.

The published results regarding fracture properties are very broad, for example, A. Bensely et al. ${ }^{18}$ and D. Yun et al. ${ }^{19}$ reported a significant improvement in the impact toughness, ranging between 15-30\% in DCT specimens compared to conventionally treated (CHT) ones, while studying tool steels (M2, T1) and case-carburized steels. Other researchers, such as A. Molinari et al. ${ }^{20}$ and F. Cajner et al. ${ }^{21}$ concluded that these treatments did not modify the impact toughness, while D. Das et al. ${ }^{22}$ and S. Zhirafar et al. ${ }^{23}$ reported that cryogenic treatments have a detrimental effect on the impact toughness, accounting for reductions in the order of $15-30 \%$. B. Podgornik et al. ${ }^{24}$ analyzed the effect of cryogenic treatments on two P/M tool steels and one high-speed steel, using several processing routes and reporting varied results.

The purpose of this paper is to determine the influence of a cryogenic treatment on the plane-strain fracture toughness of a martensitic stainless steel, following the well-established procedures determined by ASTM standards. ${ }^{25}$

\section{MATERIALS AND METHODS}

The material used in this study was an AISI 420 martensitic stainless steel. Its chemical composition was determined using a SPECTRO SPECTROMAXX optical emission spectrometer. The results are shown in Table 1 along with the reference composition taken from the ASTM A176 standard. ${ }^{26}$

A normalized bar with a diameter of $42 \mathrm{~mm}$ was cut into transversal slices, from which disk-shaped compact $[\mathrm{DC}(\mathrm{T})]$ specimens were machined according to the specifications of the ASTM E399 standard $^{25}$, with a radial- circumferential (R-C) notch configuration. The characteristic dimension (W) of the specimens was 25.4 $\mathrm{mm}$. Except for the notch, all the machining was performed before the heat treatment in order to avoid thermal cracking or an accumulation of residual tensions at the tip of the notch. After the completion of the heat treatment, notches ending in a chevron tip were made by electro-erosion.

Two groups of specimens were prepared, namely, a conventionally heat-treated one (CHT), whose specimens were quenched in oil from $1030{ }^{\circ} \mathrm{C}$ and afterwards tempered at $410{ }^{\circ} \mathrm{C}$ for $10 \mathrm{~min}$ with furnace cooling. The specimens from the other group were quenched in oil from $1030{ }^{\circ} \mathrm{C}$ and then soaked in liquid nitrogen at an equilibrium temperature of $-196{ }^{\circ} \mathrm{C}$. The specimens were lowered into a vacuum flask containing liquid nitrogen, using a low-speed motor controlled with a closed-loop system using the feedback from the thermocouple attached to each specimen. The cooling rate was set at $0.45{ }^{\circ} \mathrm{C} / \mathrm{s}$, while the soaking time was $2 \mathrm{~h}$. Finally, the specimens were tempered at $410{ }^{\circ} \mathrm{C}$ for $10 \mathrm{~min}$ and slowly cooled inside the furnace. The latter group was identified as DCT. Both the austenization/ quenching and the tempering were performed in an argon atmosphere to prevent decarburization.

For the microstructural characterization, a CARL ZEISS EVO 40 XVP scanning electron microscope was employed to evaluate mirror-polished samples attacked with Marble's reagent $\left(10 \mathrm{~g} \mathrm{CuSO}_{4}\right.$ in $50 \mathrm{~mL} \mathrm{HCl}$ and $50 \mathrm{~mL}$ water). The Vickers hardness of the specimens was measured using a FUTURE TECH FM-300 microdurometer, with the applied normal load of 500 gf. An open-source image-analysis software (Icy version 1.3.6.0 $)^{27}$ with a spot-detection plug-in was used for determining the fraction area of carbides in SEM images, as well as the mean distance between the particles, considering the average between each particle and its closest five neighbors.

X-ray diffractometry was performed using a PANALYTICAL X'PERT-MPD diffractometer (Cu- $K_{\alpha}$ radiation $-\lambda=0.15405 \mathrm{~nm}$ ) at an acceleration potential of $40 \mathrm{kV}$. The diffraction angle ranged from $20-120^{\circ}$ with a $0.02^{\circ}$ step at a speed of $0.06^{\circ} / \mathrm{min}$. The diffractometer was equipped with a graphite diffracted-beam collimator and a programmable receiving slit of $0.2 \mathrm{~mm}$, a divergence slit of $0.4^{\circ}$ and an incident and collecting slit of $1^{\circ}$.

\subsection{Fracture tests}

For obtaining the required fatigue crack, a pre-cracking machine with displacement control was used with a maximum displacement of $0.25 \mathrm{~mm}$ at a frequency of $50 \mathrm{~Hz}$. The theoretical $K_{\max }$ applied during the pre-cracking process was $20 \mathrm{MPa} \mathrm{m}^{1 / 2}$. In all the cases, the minimum pre-crack length was between $1 \cdot 10^{5}$ and $1.5 \cdot 10^{6}$ cycles, in accordance with the ASTM E399 recommendations. This set-up was chosen in order to avoid plastic deformation above the maximum levels allowed by the standard in the surroundings of a crack tip (Equation (3)). ${ }^{3}$

Plane-strain fracture tests were performed in a screw-driven AMSLER vibrophore, using a load cell of $20 \mathrm{kN}$ of the maximum capacity operating under displa-

Table 1: AISI 420 chemical composition, in mass fractions $(w / \%)$

\begin{tabular}{|c|c|c|c|c|c|}
\hline & $\mathrm{C}$ & $\mathrm{Cr}$ & $\mathrm{Mn}$ & $\mathrm{P}$ \\
\hline Bar & 0.17 & 12.83 & 0.76 & 0.05 \\
\hline AISI 420 Spec. & $0.15 \mathrm{~min}$ & $\begin{array}{l}12.00 \\
14.00\end{array}$ & $1.00 \mathrm{max}$ & $0.04 \max$ \\
\hline
\end{tabular}


G. PRIETO et al.: INFLUENCE OF A CRYOGENIC TREATMENT ON THE FRACTURE TOUGHNESS ...

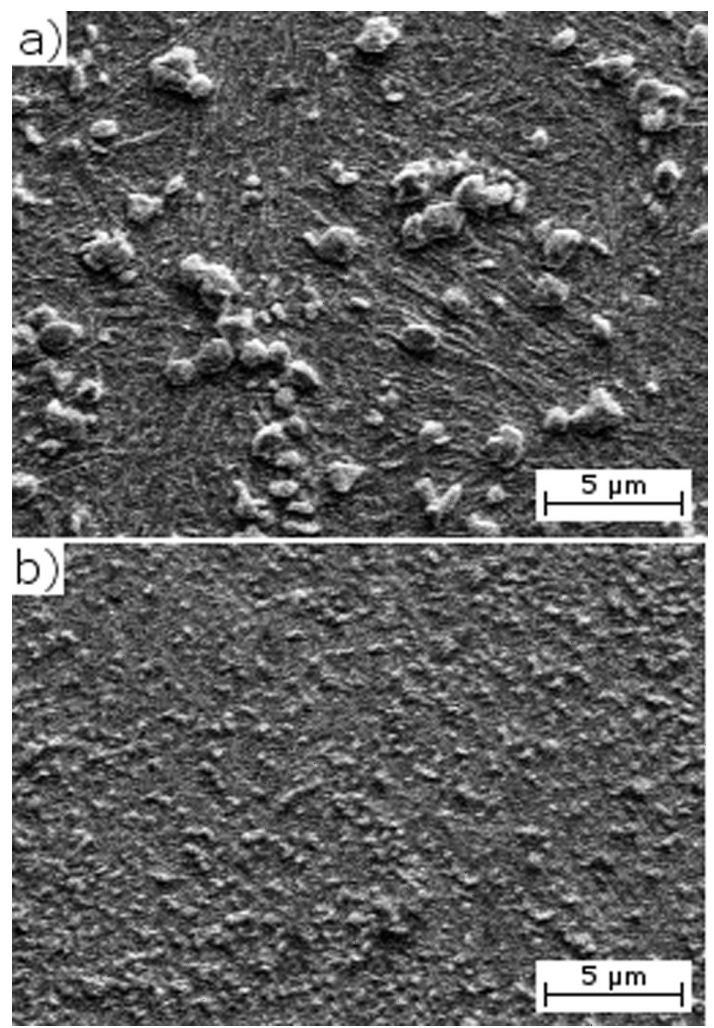

Figure 1: Secondary electron images (SEI) of: a) CHT specimen and b) DCT specimen, showing the carbide distributions

cement control, with a cross-head speed of $0.6 \mathrm{~mm} / \mathrm{min}$. The displacement of the load line was continuously recorded during the test using a linear displacement transducer (OMEGA LD600-25) sensing the movement of the machine's carriage.

After fracturing the specimens, they were scanned with a desktop flatbed scanner ${ }^{28}$ in order to measure the average crack length. For this purpose, the size of the original crack and the final physical-crack size were measured at nine equally spaced points centered about the specimen centerline at a distance $(d)$ of $1.38 \mathrm{~mm}$, according to Equation (1) established by the ASTM E1820 standard: ${ }^{29}$

$$
d=\frac{(B-0.01 W)}{9}
$$

where:

$B$ : specimen thickness, in $\mathrm{mm}$,

$W$ : specimen width, in $\mathrm{mm}$.

The obtained load vs. load-line displacement (DLL) records were analyzed in order to assess the type of fracture while the conditional plane-strain fracture toughness $\left(K_{\mathrm{q}}\right)$ was calculated according to Equation (3) taken from reference. ${ }^{25}$ If all the required conditions of linearity and small-scale plasticity were met, this $K_{\mathrm{q}}$ value was considered as $K_{\mathrm{IC}}$ :

$$
K_{\mathrm{q}}=\frac{P_{\mathrm{q}}}{\sqrt{(B W)}} \times f(a / W)
$$

where:

$K_{\mathrm{q}}$ : plane-strain fracture toughness $\left(\mathrm{MPa} \mathrm{m}^{1 / 2}\right)$,

$P_{\mathrm{q}}$ : maximum load $(\mathrm{kN})$,

$B$ : specimen thickness $(\mathrm{cm})$,

$W$ : specimen width $(\mathrm{cm})$,

$f(a / W)$ : crack-length polynomial factor where a is the average crack length. The terms of this polynomial for DC(T) specimens are detailed in Annex A3 of the ASTM E1820 standard. ${ }^{29}$

In order to evaluate the validity of the test, the $K_{\mathrm{q}}$ value and the average crack length were compared using Equation $(2)^{25}$, which guaranteed that the plastic deformation at the tip of the crack was sufficiently small to apply linear fracture mechanics. The yield stress $\left(\sigma_{\mathrm{Y}}\right)$ for the quenched and tempered AISI 420 was estimated as $1500 \mathrm{MPa}^{30}$ The reported values correspond to the average of at least three valid tests:

$$
a, B \geq 2.5\left(\frac{K_{\mathrm{q}}}{\sigma_{y}}\right)^{2}
$$

where:

$a$ : crack length, in $\mathrm{mm}$,

$B$ : specimen thickness, in $\mathrm{mm}$,

$K_{\mathrm{q}}$ : conditional plane-strain fracture toughness, in $\mathrm{MPa} \mathrm{m}{ }^{1 / 2}$,

$\sigma_{y}$ : yield stress, in $\mathrm{MPa}$.

Afterwards, the fracture surfaces were evaluated using a CARL ZEISS EVO 40 XVP scanning electron microscope in order to evaluate the micromechanisms involved in the fracture.

\section{RESULTS}

The differences in the carbide-population distribution can be seen in Figure 1, in which the CHT specimen

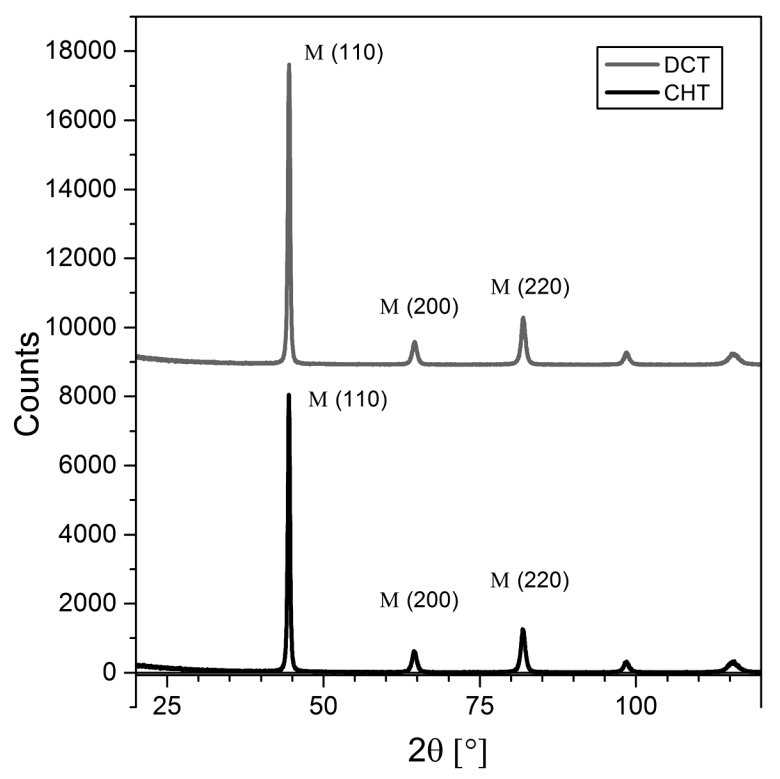

Figure 2: XRD spectra for CHT and DCT specimens 
G. PRIETO et al.: INFLUENCE OF A CRYOGENIC TREATMENT ON THE FRACTURE TOUGHNESS ...

shows larger and more isolated carbides, while in the DCT sample (Figure 1b), the carbides are smaller and closer to each other; in addition, both the distance and the volume fraction of carbides diminished. In our previous work $^{16}$, we identified these particles as globular secondary carbides of type $\mathrm{M}_{7} \mathrm{C}_{3}$ by means of an EDS analysis. The hardness, the mean distance between the carbides and the carbide volume fraction are presented in Table 2. Regarding X-Ray diffractograms, it can be seen in Figure 2 that both CHT and DCT specimens had martensitic microstructures, while austenite could not be detected; therefore, it is inferred that its volume fraction is below the detection threshold of the diffractometer (>3\% of volume fraction). The martensitic matrix shows a very fine lenticular microstructure, typical of high hardenability steels, such as AISI 420.

Table 2: Hardness and qualitative metallographic analysis

\begin{tabular}{|c|c|c|}
\hline & CHT & DCT \\
\hline Hardness (HV0.5) & $507 \pm 7$ & $534 \pm 9$ \\
\hline Distance between carbides $(\mu \mathrm{m})$ & $1.73 \pm 0.72$ & $1.37 \pm 0.46$ \\
\hline Volume fraction of carbides $(\% \mathrm{vol})$ & 16.9 & 12.2 \\
\hline Retained austenite $(\% \mathrm{vol})$ & $>3.0$ & $>3.0$ \\
\hline
\end{tabular}

Regarding the fracture-toughness tests, all the specimens exhibited a linear behavior before the sudden fracture; therefore, the maximum load $\left(P_{\max }=P_{\mathrm{q}}\right)$ was taken for the calculation of $K_{\text {IC }}$. The propagation of a crack without a load increase is characteristic of a brittle fracture. It should also be noted that no significant pop-in events developed during the tests.

Figure 3 shows the average value of $\mathrm{K}_{\mathrm{IC}}$ where it can be seen that conventionally treated specimens exhibited the average plane-strain fracture-toughness value of 49.5 MPa $\mathrm{m}^{1 / 2}$, while cryogenically treated ones showed a value of $65.0 \mathrm{MPa} \mathrm{m} \mathrm{m}^{1 / 2}$, indicating a $31 \%$ increase in comparison to conventionally heat-treated ones.

In order to inspect the nucleation mechanism prior to the sudden fracture, SEM fractographies were taken

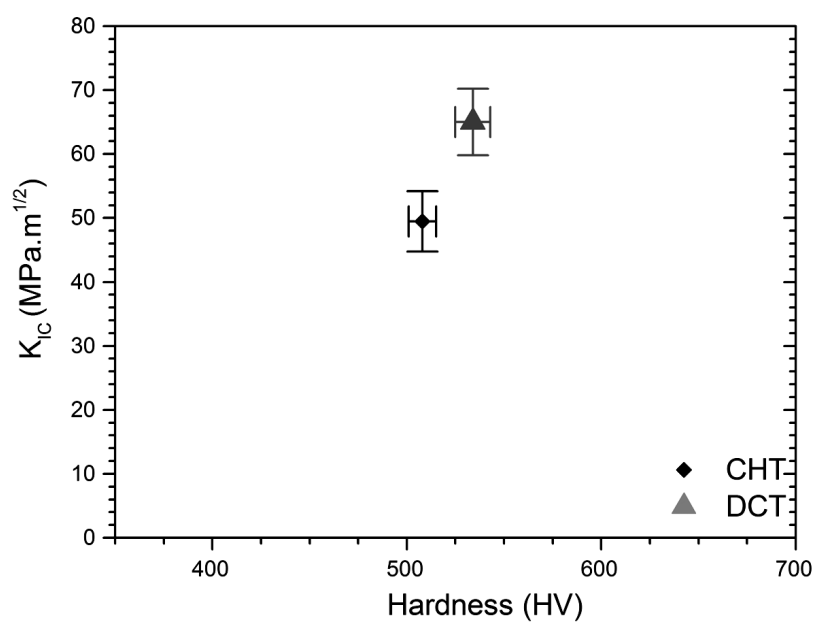

Figure 3: Plane-strain fracture toughness for conventional and cryogenically treated specimens from the middle of the specimens, at $70-80 \mu \mathrm{m}$, from the fatigue pre-crack front in the direction of propagation. Both groups of specimens showed a mixture of cleavage facets and dimples, but in the CHT ones the amount of dimples was higher (Figure 4a).

It can be appreciated that dimples are larger in the CHT specimens compared to the ones that developed in the DCT samples. Very large $(\sim 1.5 \mu \mathrm{m})$ dimples with carbides inside can be seen in Figure 4a while, in the DCT specimens, although some dimples were found, a stronger presence of ridges and cleavage facets can be seen.

\section{DISCUSSION}

Regarding the fracture behavior, it consisted of brittle fractures with no stable crack propagation. The SEM fractographies (Figure 4) showed that the microscopic failure mechanism was a confined plastic flow with a void growth responsible for crack nucleation, followed by cleavage propagation. Both groups of specimens exhibited relatively low fracture-toughness values, as expected for high-strength steels ${ }^{31}$ tested in the lower shelf region.

From the results displayed in Figure 3, it can be seen that cryogenic treatments led to a simultaneous increase in both the hardness and the plain-strain fracture toughness. The hardness increment accounted for $5 \%$, while
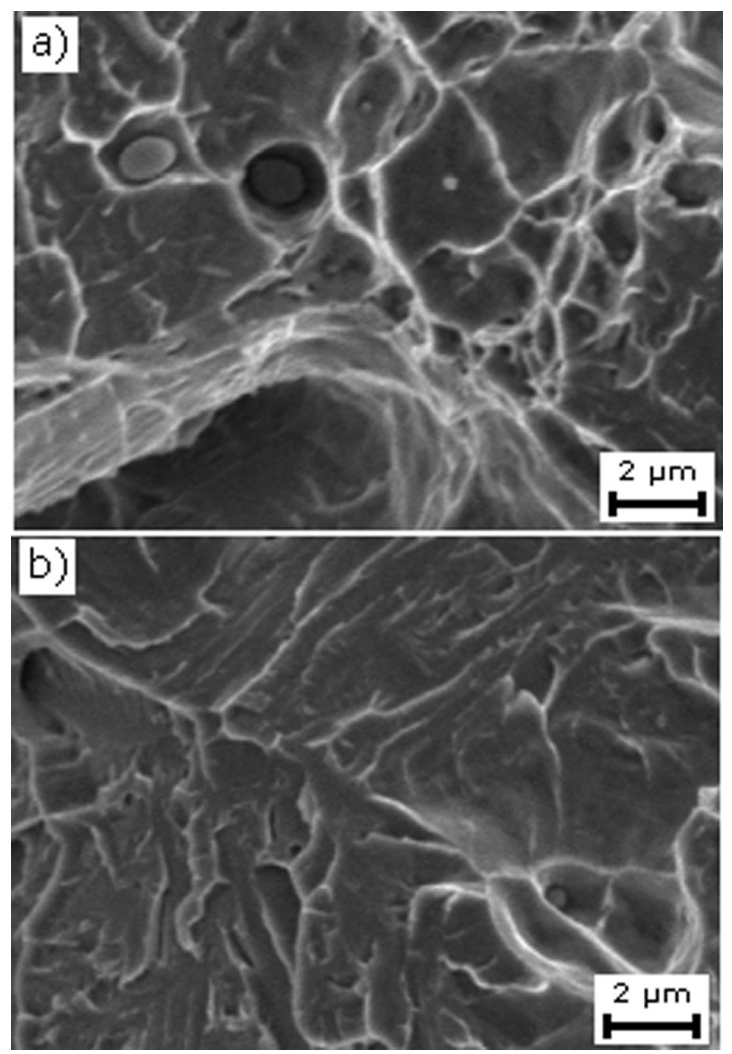

Figure 4: Secondary electron fractographies of: a) CHT and b) DCT specimens 
the average $\mathrm{K}_{\mathrm{IC}}$ value was $30 \%$ higher for the cryogenically treated specimens. It should be highlighted that, in our previous work $^{10}$, we experimentally proved that this steel has a wear-resistance increase of 35-90\% when subjected to cryogenic treatments. Therefore, the present results imply that the cryogenic treatment is an effective technique to improve simultaneously the hardness, wear resistance and fracture toughness of an AISI 420 stainless steel.

When focusing on the improvement in the fracture toughness, D. Yun et al. ${ }^{19}$ found similar results when studying cryogenically treated high-speed steels. In that case, specimens subjected to $24 \mathrm{~h}$ of soaking in liquid nitrogen, followed by triple tempering exhibited hardness and impact-toughness improvements of $2 \%$ and $30 \%$, respectively. A. B. Prabhakaran et al. ${ }^{32}$ reported a $14 \%$ increase in the impact toughness combined with a $3.5 \%$ increase in the hardness of a cryogenically treated case carburized steel, while A. Molinari et al. ${ }^{20}$ reported that the cryogenic treatment increased the toughness measured by means of three-point bending tests - influencing neither the hardness nor the impact toughness.

On the contrary, D. Das et al. ${ }^{33}$ found that a deep cryogenic treatment improved the hardness of an AISI D2 die steel by $\sim 4.5 \%$ at the expense of a fracturetoughness reduction of $\sim 7 \%$. It is interesting to note that in their case the dispersion of $K_{\mathrm{IC}}$ values was significantly higher for the DCT specimens compared to the CHT ones, whereas our results indicate that these values were very similar. In that paper, Das and his collaborators emphasized the role of the size and distribution of secondary carbides, reporting a reduction in their size and their higher volume fraction.

Regarding the influence of cryogenic treatments, B. Podgornik et al. ${ }^{24}$ found dissimilar behaviors of the fracture properties of $\mathrm{P} / \mathrm{M}$ and high-speed steels. In the case of the P/M cold-work tool steel, the improvement in the fracture toughness was associated with the formation of finer needles of martensite in combination with the plastic deformation of primary martensite, a reduced amount of dissolved carbon in the martensite and a finer distribution of carbides.

In Figure 2, it can be seen that AISI 420 exhibits negligible amounts of retained austenite - less than $3 \%$ of volume fractions even when it is subjected to the conventional heat treatment. This result can be supported with the findings of Da Sun et al. ${ }^{14}$ obtained during a study of the microstructure of a laser-cladding coating made of AISI 420, in which the volume of retained austenite was below the detection limit of the diffractometer. S. Dodds et al. ${ }^{15}$ also reported XRD patterns of as-quenched AISI 420 samples, where no reflections corresponding to the retained austenite could be seen. The importance of these results is that they show that AISI 420 does not retain significant amounts of austenite, not even in the untempered condition. Therefore, we can infer that the mechanism of the deformation of primary martensite proposed by A. I. Tyshchenko et al. ${ }^{11}$ can be considered marginal in the cryogenic processing of AISI 420. For this reason, we will carry out further studies to deepen the understanding of the metallurgical effects of cryogenic treatments on steel alloys.

In our case, we propose that the main mechanism responsible for the fracture-toughness increase is the refinement of carbides (Figure 1) as a consequence of the cryogenic cooling. Due to their different mechanical properties compared to the metallic matrix, carbides act as stress concentrators; thus, a reduction in their size leads to a decrease in the stress concentration ${ }^{34}$, especially in the surroundings of a crack tip.

In addition, the early results reported by D. A. Curry and J. F. Knott ${ }^{35}$ noted a detrimental influence of coarse carbides on the fracture toughness, while P. Bowen et al. ${ }^{36}$ showed that carbides with diameters of above $0.3 \mu \mathrm{m}$ were critical in the controlling of the fracture toughness. Similarly, X. Z. Zhang and J. F. Knott ${ }^{37}$ concluded that carbides act as critical microcrack nuclei and highlighted the importance of having finely dispersed microstructural features in order to increase the $\mathrm{K}_{\mathrm{IC}}$ values. In this sense, the coarser carbides in the CHT samples shown in Figure 1a promote the formation of larger dimples (Figure 4a) that coalesce at lower stresses forming larger cavities in the material. It should be noted that there was no evidence of carbide fracturing; therefore, the main fracture micromechanism was the aforementioned void coalescence phenomenon followed by cleavage. This way, the refinement of the carbide size and distribution due to the cryogenic treatment (Figure 2b) can be associated with the subsequent increase in the fracture toughness shown in Figure 3.

\section{CONCLUSIONS}

On the basis of the results obtained from the study of the fracture toughness of a cryogenically treated martensitic AISI 420 stainless steel, we conclude that there is a synergistic relationship between the carbide-size diminution generated by cryogenic cooling, which lowers the stress-concentration effect on the surroundings and, therefore, the void formation and coalescence, and the reduction in the volume fraction that lowers the probability of cleavage-fracture occurrence. This way, we can link the microstructural modifications induced by the cryogenic treatments with the simultaneous increase in both the hardness and fracture toughness.

\section{Acknowledgments}

The authors would like to thank Dr. Héctor G. Kotik and Mr. Eduardo G. Benotti from Universidad Nacional del Comahue for their assistance in performing the fracture tests. Funding was provided by Agencia Nacional de Promoción Científica y Tecnológica by means of the grant PICT 2013-0616. 


\section{MATERIALI IN TEHNOLOGIJE/MATERIALS AND TECHNOLOGY (1967-2017) - 50 LET/50 YEARS}

\section{G. PRIETO et al.: INFLUENCE OF A CRYOGENIC TREATMENT ON THE FRACTURE TOUGHNESS ...}

\section{REFERENCES}

${ }^{1}$ R. F. Barron, Cryogenic treatment of metals to improve wear resistance, Cryogenics, 22 (1982), 409-413

${ }^{2}$ D. Das, A. K. Dutta, K. K. Ray, Correlation of microstructure with wear behaviour of deep cryogenically treated AISI D2 steel, Wear, 267 (2009), 1371-1380, doi:10.1016/j.wear.2008.12.051

${ }^{3}$ V. Leskovšek, M. Kalin, J. Vižintin, Influence of deep-cryogenic treatment on wear resistance of vacuum heat-treated HSS, Vacuum, 80 (2006) 507-518, doi:10.1016/j.vacuum.2005.08.023

${ }^{4}$ V. G. Gavriljuk, W. Theisen, V. V. Sirosh, E. V. Polshin, A. Kortmann, G. S. Mogilny, Low-temperature martensitic transformation in tool steels in relation to their deep cryogenic treatment, Acta Mater., 61 (2013), 1705-1715, doi:10.1016/j.actamat.2012.11.045

${ }^{5}$ A. Bensely, A. Prabhakaran, G. Nagarajan, Effect of cryogenic treatment on distribution of residual stress in case carburized En 353 steel, Mater. Sci. Eng. A, 479 (2008), 229-235

${ }^{6}$ D. Das, A. K. Dutta, K. K. Ray, Sub-zero treatments of AISI D2 steel: Part II. Wear behavior, Mater. Sci. Eng. A, 527 (2010), 2194-2206, doi:10.1016/j.msea.2009.10.071

${ }^{7}$ D. Das, A. K. Dutta, Optimization of the duration of cryogenic processing to maximize wear resistance of AISI D2 steel, Cryogenics, 49 (2009), 176-184

${ }^{8}$ F. Meng, K. Tagashira, H. Sohma, Wear resistance and microstructure of cryogenically treated $\mathrm{Fe}-1.4 \mathrm{Cr}-1 \mathrm{C}$ bearing steel, Scr. Metall. Mater., 31 (1994), 865-868

${ }^{9}$ F. Meng, T. Kohsuke, R. Azuma, H. Sohma, Role of eta-carbide precipitations in the wear resistance improvements of $\mathrm{Fe}-12 \mathrm{Cr}-\mathrm{Mo}$ $\mathrm{V}-1.4 \mathrm{C}$ tool steel by cryogenic treatment, ISIJ Int., 34 (1994), 205-210

${ }^{10}$ G. Prieto, W. R. Tuckart, Wear behavior of cryogenically treated AISI 420 martensitic stainless steel, Proc. of VIII Iber. Conf. Tribol., Cartagena, Spain, 2015, 68-75

${ }^{11}$ A. I. Tyshchenko, W. Theisen, A. Oppenkowski, S. Siebert, O. N. Razumov, A. P. Skoblik, Low-temperature martensitic transformation and deep cryogenic treatment of a tool steel, Mater. Sci. Eng. A, 527 (2010), 7027-7039, doi:10.1016/j.msea.2010.07.056

${ }^{12}$ V. G. Gavriljuk, V. A Sirosh, Y. N. Petrov, A. I. Tyshchenko, W. Theisen, A. Kortmann, Carbide Precipitation During Tempering of a Tool Steel Subjected to Deep Cryogenic Treatment, Metall. Mater. Trans. A, 45 (2014), 2453-2465, doi:10.1007/s11661-014-2202-8

${ }^{13}$ M. Villa, K. Pantleon, M. A. J. Somers, Evolution of compressive strains in retained austenite during sub-zero Celsius martensite formation and tempering, Acta Mater., 65 (2014), 383-392, doi:10.1016/j.actamat.2013.11.007

${ }^{14}$ S. Da Sun, D. Fabijanic, A. Ghaderi, M. Leary, J. Toton, S. Sun, Microstructure and hardness characterisation of laser coatings produced with a mixture of AISI 420 stainless steel and Fe-C-Cr-Nb-B-Mo steel alloy powders, Surf. Coatings Technol., 296 (2016), 76-87, doi:10.1016/j.surfcoat.2016.03.061

${ }^{15} \mathrm{~S}$. Dodds, A. H. Jones, S. Cater, Tribological enhancement of AISI 420 martensitic stainless steel through friction-stir processing, Wear, 302 (2013), 863-877, doi:10.1016/j.wear.2013.01.007

${ }^{16}$ G. Prieto, J. E. Perez Ipiña, W. R. Tuckart, Cryogenic treatments on AISI 420 stainless steel: Microstructure and mechanical properties, Mater. Sci. Eng. A, 605 (2014), 236-243, doi:10.1016/j.msea.2014. 03.059

${ }^{17}$ G. Prieto, Estudio del efecto de tratamientos térmicos de criogenia sobre el comportamiento tribológico y la tenacidad a la fractura del acero AISI 420, Universidad Nacional del Sur, 2016.
${ }^{18}$ A. Bensely, A. Prabhakaran, D. Mohan Lal, G. Nagarajan, Enhancing the wear resistance of case carburized steel (En 353) by cryogenic treatment, Cryogenics, 45 (2005), 747-754, doi:10.1016/ j.cryogenics.2005.10.004

${ }^{19}$ D. Yun, L. Xiaoping, X. Hongshen, Deep Cryogenic Treatment of High-Speed Steel and its Mechanism, Heat Treat. Met., 3(1998), 55-59

${ }^{20}$ A. Molinari, M. Pellizzari, S. Gialanella, G. Straffelini, K. H. Stiasny, Effect of deep cryogenic treatment on the mechanical properties of tool steels, J. Mater. Process. Technol., 118 (2001), 350-355, doi:10.1016/S0924-0136(01)00973-6

${ }^{21}$ F. Cajner, V. Leskovšek, D. Landek, H. Cajner, Effect of deep-cryogenic treatment on high speed steel properties, Mater. Manuf. Process., 24 (2009), 743-746

${ }^{22}$ D. Das, K. K. Ray, Structure-property correlation of sub-zero treated AISI D2 steel, Mater. Sci. Eng. A, 541 (2012), 45-60, doi:10.1016/ j.msea.2012.01.130

${ }^{23}$ S. Zhirafar, A. Rezaeian, M. Pugh, Effect of cryogenic treatment on the mechanical properties of 4340 steel, J. Mater. Process. Technol., 186 (2007), 298-303, doi:10.1016/j.jmatprotec.2006.12.046

${ }^{24}$ B. Podgornik, I. Paulin, B. Zajec, S. Jacobson, V. Leskovšek, Deep cryogenic treatment of tool steels, J. Mater. Process. Technol., 229 (2016), 398-406, doi:10.1016/j.jmatprotec.2015.09.045

${ }^{25}$ ASTM E399-12e3, Standard Test Method for Linear-Elastic Plane-Strain Fracture Toughness KIc of Metallic Materials, ASTM International, West Conshohocken, PA, 2012, doi:10.1520/E0399

${ }^{26}$ ASTM A176-99(2009), Standard Specification for Stainless and Heat-Resisting Chromium Steel Plate, Sheet, and Strip (withdrawn 2015), ASTM International, West Conshohocken, PA, 2009, doi:10.1520/A0176-99R09

${ }^{27}$ F. de Chaumont et al., Icy: an open bioimage informatics platform for extended reproducible research, Nat. Methods, 9 (2012), 690-696

${ }^{28}$ I. Korin, C. Larrainzar, J. E. Perez Ipiña, Crack length and stable crack extension measurements from images acquired by means of a conventional flatbed scanner, Fatigue Fract. Eng. Mater. Struct., 31 (2008), 876-884

${ }^{29}$ ASTM E1820-13e1, Standard Test Method for Measurement of Fracture Toughness, ASTM International, West Conshohocken, PA, 2013, doi:10.1520/E1820-13E01

${ }^{30}$ ASM Handbook, Vol. 19, Materials Park, OH, ASM International, 1996

${ }^{31}$ JSMS, Data book on fracture toughness for metallic materials, Kyoto, 1995

${ }^{32}$ A. B. Prabhakaran, G. Nagarajan, D. M. Lal, Effect of cryogenic treatment on impact strength of case carburized steel En 353, Proc. IMEC2004 Int. Mech. Eng. Conf., Kuwait, 2004

${ }^{33}$ D. Das, R. Sarkar, A. K. Dutta, K. K. Ray, Mater. Sci. Eng. A, 528 (2010), 589-603, doi:10.1016/j.msea.2010.09.057

${ }^{34}$ A. S. Pandkar, N. Arakere, G. Subhash, Microstructure-sensitive accumulation of plastic strain due to ratcheting in bearing steels subject to rolling contact fatigue, Int. J. Fatigue, 63 (2014), 191-202, doi:10.1016/j.ijfatigue.2014.01.029

${ }^{35}$ D. A. Curry, J. F. Knott, Effect of microstructure on cleavage fracture toughness of quenched and tempered steels, Met. Sci., 13 (1979), 341-345

${ }^{36}$ P. Bowen, S. G. Druce, J. F. Knott, Effects of microstructure on cleavage fracture in pressure vessel steel, Acta Metall., 34 (1986), 1121-1131

${ }^{37}$ X. Z. Zhang, J. F. Knott, Cleavage fracture in bainitic and martensitic microstructures, Acta Metall., 47 (1999), 3483-3495 